during the past ten years. Further details can be obtained from the Secretary, Illuminating Engineering Society, 32 Victoria Street, London, S.W.I.

\section{Aslib Winter Meeting}

THE winter meeting of Aslib will be held at the Institution of Electrical Engineers (Savoy Place, London, W.C.2) on March 8, at 5.30 p.m., under the chairmanship of Mr. L. J. F. Brimble. Mr. F. C. Francis, of the British Museum, will speak on "The British National Bibliography", and Mr. W. Cox, of H.M. Stationery Office, on "Government Publications with Special Reference to the Card Index Service". Discussions will follow. The meeting is open to members and guests.

\section{Conference on Mental Health and the Family}

A conference on "Mental Health and the Family" has been organised by the National Association for Mental Health and will be held at Seymour Hall, Seymour Place, London, W.1, during March 23-24. The conference will be opened by the Archbishop of Canterbury. The topics for the four sessions are : social health in the twentieth century ; mental health in young children; education and mental health (childhood and adolescence); on the assumption of maturity. Tickets of admittance (including the printed report) cost 25s. and can be obtained from the Conference Secretary, 39 Queen Anne Street, London, W.1.

\section{Conference on World's Food and Britain's Needs}

THe Association of Scientific Workers is holding a conference on "The World's Food and Britain's Needs" at St. Pancras Town Hall, Euston Road, London, W.C.1, during March 4-5. Lord Boyd Orr will preside. The conference is designed not merely to direct attention to the urgency of the food problem, but also to show how it can be tackled scientifically. The programme will be divided into three sessions, with speakers and their subjects as follows: Session 1, Dr. Julian S. Huxley, "Population Problems", and Mr. F. Le Gros Clark, "The World's Food Problems"'; Session 2, Sir George Stapledon, "Britain's Needs and Possibilities", Dr. G. A. Reay, "Fish Utilization", and Mr. S. A. Barnett, "Prevention of Food Losses", Session 3, Mr. Ritchie Calder, "Food from Waste Materials", and Lord Boyd Orr, "World Resources and the Distribution of the World's Food". The conference will open with the showing of the documentary film "The World is Rich", by Paul Rotha, and will end with a résumé by Mr. F. Le Gros Clark, entitled "Conference Survey and Future Action". The delegation fee to the conference is 10s. per delegate; visitors' tickets are $2 s$. $6 d$. per session, obtainable from the General Secretary, Association of Scientific Workers, 15 Half Moon Street, Piccadilly, London, W.1.

\section{International Congress on Analytical Chemistry}

As International Congress on Analytical Chemistry will be held in Great Britain in 1952. At the meeting of the International Union of Pure and Applied Chemistry in Amsterdam in September, it was decided that six autonomous sections should be formed, one of which would be concerned with analytical chemistry ; and it is hoped that a meeting of the board of this provisionally constituted section on analytical chemistry may be arranged to coincide with the Congress in Britain. The honorary secretary of the
Congress is Mr. R. C. Chirnside, Research Laboratories of the General Electric Co., Ltd., Wembley, Middlesex.

\section{Nuffield Foundation Awards in Dentistry}

To help the advancement of teaching and research on dental health and disease, the Nuffield Foundation is offering a number of fellowships to enable selected men and women with dental qualifications to receive additional training in pure and applied science that will fit them for an academic career in dentistry, and also to enable selected university graduates in medicine and science to receive training that will qualify them to undertake teaching and fundamental research on dental health and disease; in the latter case, however, it is not expected that every fellow will necessarily study to obtain a registerable dental qualification. The annual value of such fellowships is $£ 500-800$, and they will be awarded for one to three years. Scholarships, normally tenable for one year, are also available for students at university dental schools in the United Kingdom; these scholarships cover tuition fees and include a subsistence allowance of value not more than $£ 200$ a year. Application forms for fellowships must be returned by March 31, and for scholarships by June 30; the forms are obtainable from the Secretary of the Nuffield Foundation, 12 and 13 Mecklenburgh Square. London, W.C.l.

\section{Announcements}

M. Antorne Lacassagne has been elected an academicien libre of the Paris Academy of Sciences in succession to the late M. Gustave Roussy.

THe thirty-fourth Guthrie Lecture of the Physical Society will be given by Prof. G. I. Finch at 5 p.m. on March 3 at the Science Museum, Exhibition Road, South Kensington, London, S.W.7. Prof. Finch is the immediate past president of the Physical Society and is well known for his work on electron diffraction. The Lecture, entitled "The Sliding Surface", will be a discussion of the phenomena of wear and lubrication at the sliding surface.

THE following appointments in the University of Manchester have recently been announced: reader in mathematies, M. J. Lighthill ; reader in pharmaceutical chemistry, Dr. K. Bullock; senior locturer in mathematics, G. N. Ward ; lecturer in physics, J. A. Newth ; lecturer in chemistry, M. C. Whiting.

NEw officers of the British Non-Ferrous Metals Research Association have been elected as follows: the Hon. R. M. Preston, chairman of Council, in succession to Sir John Greenly; Mr. F. C. Braby, vice-chairman and honorary treasurer; and Dr. Maurice Cook, chairman of the Research Board.

Applications are invited for Lady Tata Memorial Fund grants and scholarships to scientific workers of any nationality for research in diseases of the blood, with special reference to leukremia, in the year beginning October 1, 1950. Grants are made for research expenses, and scholarships are awarded as personal remuneration, their normal value being $\mathfrak{£ 4 0 0}$ per annum. Applications must be submitted befor $\theta$ March 31, and the awards will be announced in June. Further particulars and forms of application may be obtained from the Secretary of the Scientific Advisory Committee, Lady Tata Memorial Fund, c/o Medical Research Council, 38 Old Queen Street, Westminster, London, S.W.I. 